seventeen of the most pleasing walking routes through Glen Trool. The Gaelic derivations and English versions of the place names are enumerated by Kevan McDonald, while the Guide also contains suggestions to help newcomers to Glen Trool to find their way to and about the Park.

\section{Experiments on the Cornish Pilchard Fishery}

AN account by Dr. W. C. Hodgson and Mr. I. D. Richardson of some experiments conducted on the Cornish pilchard fishery during 1947-48 is given in a recent Ministry of Agriculture and Fisheries publication (Fishery Investigations, Series 2, 17, No. 2 : The Experiments on the Cornish Pilchard Fishery in 1947-48; pp. 21 . London : H.M. Stationery Office, 1949. 2s. net). The aim of the experiments was primarily to establish whether or not the landings of pilchards can be increased or stabilized so that the canning factories may receive adequate and stcady supplies of these fish in order to offset the loss of imported canned pilchards. A general survey of the fishing area between Plymouth and Mevagissey was made, employing a ring net such as is used by Scottish east-coast fishermen for herrings. The net was slightly modified, but, even so, was not quite suitable for pilchard work. Echo-sounders were used for locating the shoals, augmented on occasion by the Scottish 'feeling wire' method of fish detection. The experiments showed most convincingly the extraordinary effectiveness of the echo-sounder in locating pilchard shoals and in determining their extent and depth. With echo-sounders in use, therefore, precision fishing, in regard to both place and depth, becomes possible, with resultant increase of catches and reduction of time and expense. A number of very striking ochosounder 'traces' of pilchard shoals is given. During the survey, opportunity was taken to make various scientific observations on the natural history and biology of pilchards in Cornish waters.

\section{Bird Ringing in 1949}

THE thirteenth report of the Bird Ringing Committee of the British Trust for Ornithology shows that the ringing of a total of 57,461 birds in 1949 exceeded the previous highest total of 1939 by 1,644 (British Birds, 43, No. 6; June 1950). The largest single contributions to the list come from the bird observatories. Among species ringed for the first time were the black-headed bunting, rustic bunting, blackeared wheatear, greenish warbler, purple sandpiper and bar-tailed godwit, while starlings were successfully ringed at roosts in Trafalgar Square by members of the London Natural History Society.

Individual recoveries of special interest include the first from abroad in the case of the lesser redpoll, two ringed as nestlings in the north of England having been reported in Belgium. A reed-warbler and $a$ roseate tern, both recovered in September in Douro Province, Portugal, were also the first of their species to be reported from abroad. A linnet ringed as a nestling in Leicestershire and recovered in October at Cuenca, Spain, and a meadow-pipit ringed as a nestling in Fife and recovered in December at Mazagan, western Morocco, represent the most southerly records for ringed birds of these species. A record of a starling, ringed in Sussex in early November and recovered at Bordeaux three weeks later, is the first of its kind, and suggests a bird of different native origin from most of the winter visitors to Britain of this species. Fast travelling was shown by a wheatear ringed in Skokholm in August and recovered in Landes, France, two days later, while longevity was shown by a teal ringed in Northern Ireland and shot near Lisbon in its eleventh year.

\section{The Amsterdam Naturalist}

Is Holland, as elsewhere, the number of scientific journals intended for specialists is very large, while most of the popular publications are often of little interest to the more scientifically minded. Members of the staff of the Zoological Museum, Amsterdam, have therefore decided to produce a monthly journal of real scientific standing adapted to meet the needs of the general reader. The journal has been called The Amsterdam Naturalist, and the first issue appeared in April 1950. In this issue are articles on the emperor penguin by $K$. H. Voous, a re-diagnosis of the fish genera Wannostomus and Pceilobycon by J. J. Hoedeman and tumours in whales by A. Stoik; the journal also contains a section of notes and news. All articles are in English, and contributions to future issues are invited from biologists and naturalists. The annual subscription is $16 s$.

\section{Preparation of Scientific Papers}

A PAMPHLET, entitled "General Notes on the Preparation of Scientific Papers" (pp. 26. London : Cambridge University Press, 1950. 2s. 6d. net), has been prepared by a subcommittee of the Information Services Committee of the Royal Society, under the chairmanship of Prof. G. L. Brown, as the outcome of concern expressed at the Royal Society's Scientific Information Conference in 1948 about the quality of scientific papers presented for publication. The pamphlet is of a general nature and is concerned with the presentation rather than with the writing of scientific papers. It is intended to supplement and not replace those specific instructions to authors which are issued by many societies and other publishing bodies, and it emphasizes a number of points in the latter instructions to which authors should pay stricter attention. Some sections of the pamphlet should also be of assistance to typists copying papers, and some of the sections, such as those dealing with nomenclature, symbols and abbreviations, conveniently bring together the sources of reference. The final section consists of a short bibliography which might, with advantage, be extended, for the books on writing, in particular, are too limited.

\section{Forecasting Potato Blight}

A RECENT study by Dr. John Grainger ("Forecasting Outbreaks of Potato Blight in West Scotland", Trans. Brit. Myc. Soc., 33, 82; 1950) amplifies the suggestions of Beaumont (Trans. Brit. Myc. Soc., 31,45 ; 1948) that a minimum temperature over $50^{\circ} \mathrm{F}$. and a minimum relative humidity over 75 per cent for forty-eight hours in succession would provide a suitable climate for an outbreak of potato blight within fifteen to twenty-two days. Dr. Grainger finds it necessary to specify a "zero time" (the end of June for south-west Scotland) before which such predictions would be invalid. Little correlation between the amount of foliage blight and yield could be demonstrated, although a postscript to the paper suggests that later work reveals a considerable total loss of as much as 25 per cent. A relationship appeared between the rate of development of foliage blight and the amount of blight appearing on the tubers. Years of slow development of the disease on the foliage were found to result in higher tuber 